NORDISK MUSEOLOGI $1996 \cdot 2$

Les antennes de l'Ecomusée dans la Communauté

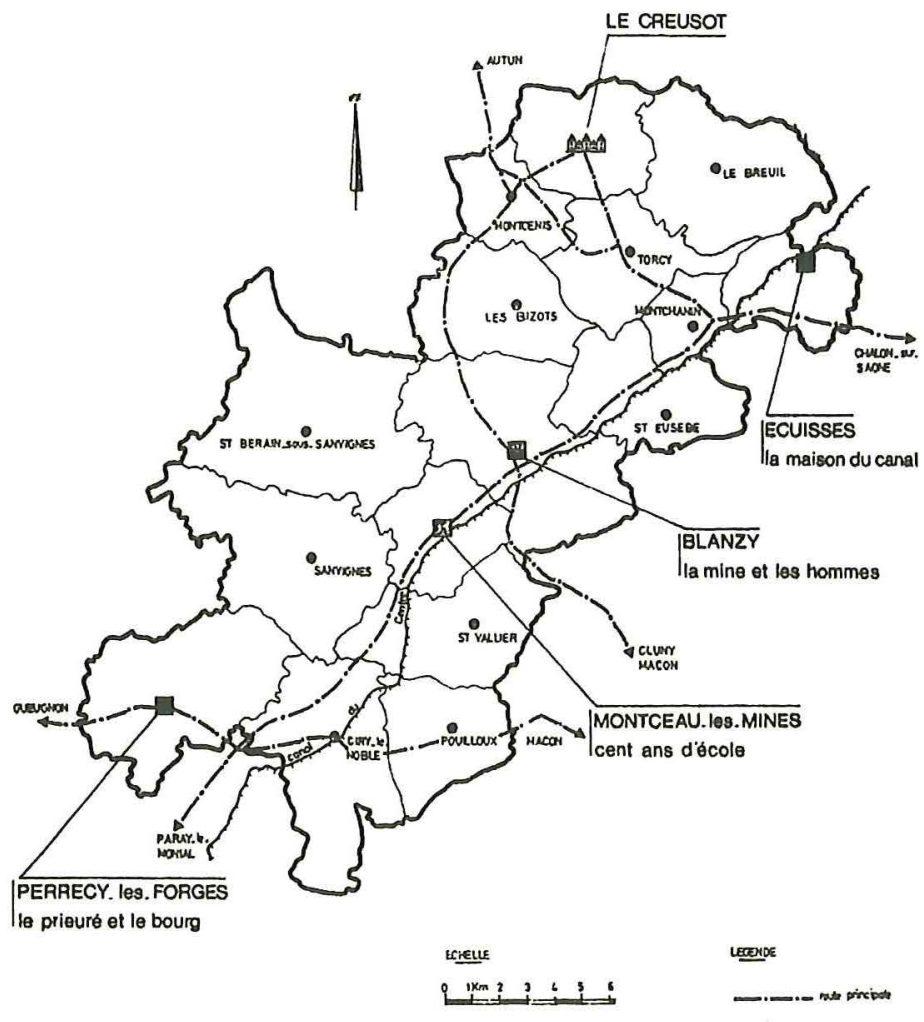

Ecomusée de la Communauté Le Creusot - Montceau.les. Mines Cháteau de la Verrerie. BP 53. 71200 Le Creusot. tél 85/55.01.11.

Kart over Le Creusot/Montceau-Les-Mines fra 1983 med museets "antenner» inntegnet, altså museets ulike avdelinger. 


\title{
ECOMUSEUM OR COMMUNITY MUSEUM? 25 YEARS OF APPLIED RESEARCH IN MUSEOLOGY AND DEVELOPMENT
}

\author{
Hugues de Varine
}

The 'applied research' referred to in the following paper was not done by me personally. It is the result of years of practice and innovation by dozens of imaginative professionals, working in the field, with limited means, fighting against the misunderstandings, or even the hostility of the authorities. I have only been an observer, even during my days as general secretary of ICOM. I now keep in touch because I am interested in the new museology as a tool for local and community development, which is my current preoccupation.

\section{THE ORIGINS IN THE 1960s}

The new museology was not born from nothing. It is the result of a long process, during the 1960s. I want to recall a number of places and cases which, in my opinion, laid the foundations for a new approach to museums, with a strong link to the politics of development.

The decade was a period of great prosperity among the countries of the "first world", of stagnation, both cultural and economic, in the second world, of liberation and self-assessment in the third world. It was also a period of social and cultural struggle on the part of minorities and oppressed groups and peoples everywhere. So it was not abnormal that, even in the traditionally stable and conservative museum world, a number of original minds would look for solutions outside the established standards. ICOM, where I worked at the time, was an ideal point from which to observe these attempts.

* In Mexico, during the same week of September 1964, seven major National Museums were inaugurated, as symbols of a multicultural nation and as educational instruments for the most marginalized sections of the population. Mario Vasquez was both the museologist 
22 and the museographer who masterminded this programme.

* In Niger, the President of the Republic, Hamani Diori, and the Chairman of the National Assembly, Boubou Hama, asked a Catalan refugee, Pablo Toucet, to create a National Museum geared towards building up national unity in a former French colony which had earned independence only a few years before.

* In the United States, as part of the fight for civil rights within the ethnic minorities and of a network of community museums in Los Angeles, New-York, Chicago and Washington, a protestant preacher, John Kinard, mobilized his African-American brethren for the creation of the "Anacostia Neighbourhood Museum» in a recycled former cinema theater.

* In India, Amalendu Bose founded with private funds the Birla Museum of Science and Industry in Calcutta, and a fleet of travelling exhibitions mounted on Land-Rovers and lorries, for the education of the masses in basic technologies.

* In Sweden, following the State commissioned report MUS 65, Riksutställningar was established, an innovation which changed in depth the language and practice of exhibitions. Under Gunnar Westin, assisted by Ulla Olofsson and others, it had a considerable influence, well outside Scandinavian borders.

All these examples had a strong political component: they tried to serve and to adapt their efforts to a common objective of development, and to give it a cultural response as well as to offer a communica- tion based on the objects and on the heritage of the communities concerned.

\section{1-1972: \\ A TURNING POINT}

It is at this point that ICOM was invited to discuss the political role of museums, at its general conference held in France in the summer of 1971 . Several ministers or former ministers from the USSR, Germany, Dahomey, France, and Mario Vasquez from Mexico were the keynote speakers. In the meantime, a reform of Icom and its statutes was launched. And it was decided to accord more attention to the role of museums in the study and protection of the environment. At this ICOM conference, which helped to mobilize the innovators among the museum profession around the world, a new word, "ecomuseum», was coined and many controversial ideas were introduced.

One year later, in May 1972, a Seminar was organized in Santiago de Chile, jointly by Unesco and ICOM, on the role of museums in contemporary Latin America. Among the speakers, all Latin American and non-museologists, was the Argentinian Jorge-Enrique Hardoy, historian of an urban development, who convincingly demonstrated the potential use of museums in meeting the major challenge of urban explosion on the American continent. As a result, the participants adopted the celebrated "Santiago Declaration" which proposed the notion of an «Integral Museum» and stated the moral obligation of museum professionals to contribute to the development policies and programmes of their respective countries. 


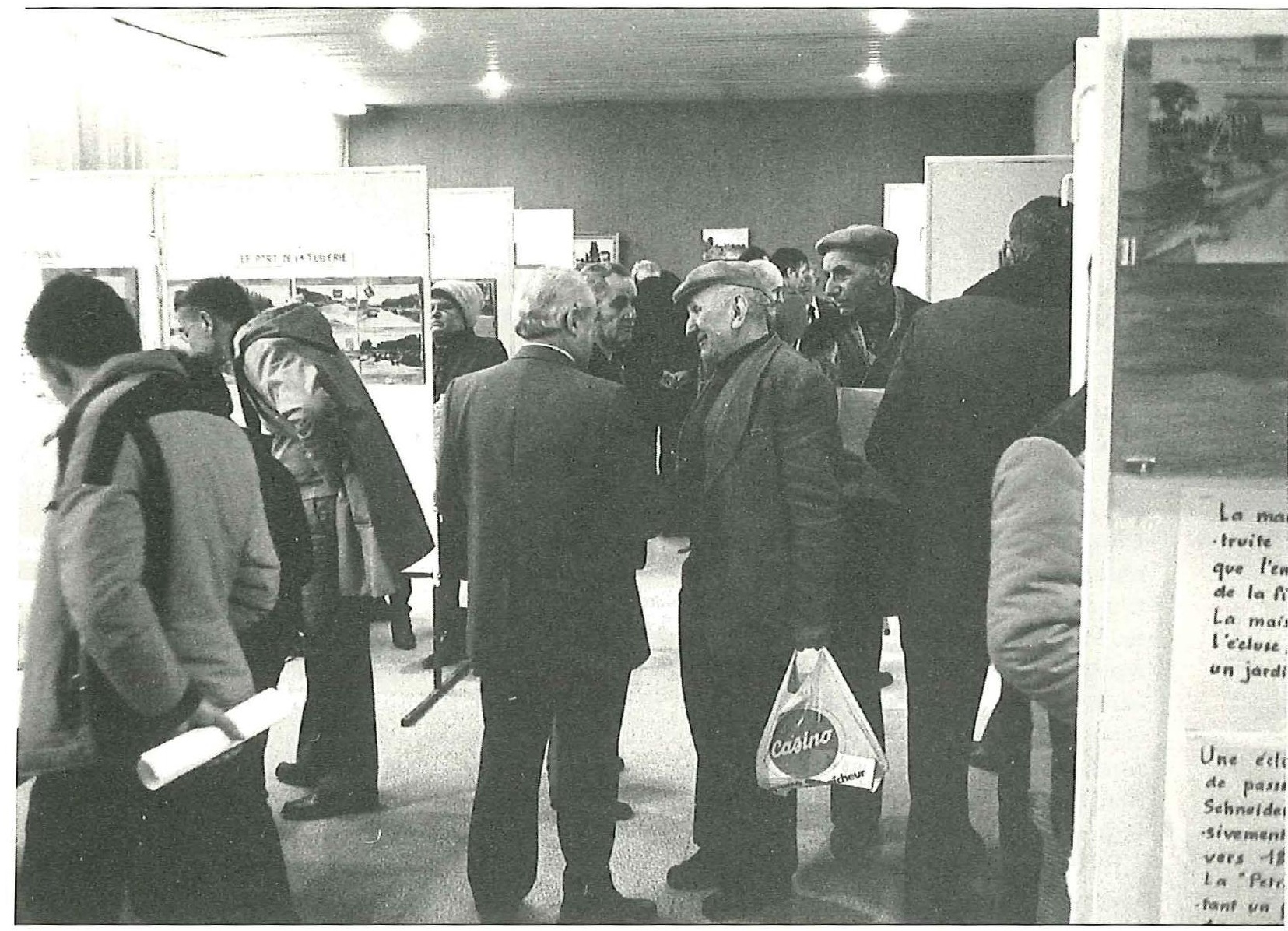

Økomuseet i Le Creusot-Montceau-Les-Mines. Transporten til og fra stålverksbyen Le Creusot gikk på "Canal du Centre». Utstillingsåpning 22. februar 1983 i den vesle byen Montchanin som var omlastingshavn. Utstillingen som handlet om kanaltransporten var laget av ei lokal arbeidsgruppe. Foto: John Aage Gjestrum.

It was also in the early 70 s that ICOM launched its first campaign against the illegal traffic in cultural property, one of the major threats to the cultural heritage of the emerging nations.

\section{FROM THE MUSEUM OF MAN} AND INDUSTRY (LE CREUSOT) TO THE ECOMUSEUM OF THE URBAN COMMUNITY LE CREUSOTMONTCEAU (1972-1980)

As all these events took place on the world museum scene, I became involved by sheer chance in a concrete museum problem in the small industrial region of Le
Creusot and Montceau, in my own province of Burgundy. Asked to cooperate in the planning of a local museum in Le Creusot, I took part, together with a small group of local community leaders, in the invention of a museum concept more suited to answering two very political questions: how to help a population of 100000 pass from a totally paternalistic era to a period of more modern capitalist industrial development, on the one hand, and from a loose network of sixteen independent and sometimes conflicting municipalities to an urban complex with a common planning, development and investment policy. 
24 It was the beginning of ten years of exciting community work, mobilizing the energies and capacities of many local leaders, associations, institutions, recruiting young people to carry out museum tasks (study, collecting, research, education, museography) for which they were eager but not prepared, etc. This museum, which later became known as an «ecomuseum» (for purely opportunistic reasons too complicated to explain here), was visited by many colleagues from all over the world and came unwillingly to be a sort of "model» (although the original concept of ecomuseum was oriented toward the environment and interpretation of nature), first for the creation of similar projects in France and then elsewhere.

I have to say right now that this ecomuseum underwent a crisis in the mid80 s, due to the aging of its main leaders and actors and a generation-shift: the founding fathers had by then reached retirement age, while a new active population was faced more with economic difficulties and unemployment than with the recognition and salvage of a collapsed industrial past. This illustration of the "generation gap" should be elaborated and studied, in order to illuminate the museum process which is at the heart of the new museology.

\section{AN INTERNATIONAL «NEW MUSEO- LOGY» MOVEMENT IN THE 80s}

It took almost ten years to integrate the principles of the new museology, established in Santiago, Le Creusot, and elsewhere, into practical museum projects in various countries. In the 80 s, suddenly, a whole family of new museums, often but not always called ecomuseums, blossomed: "museos locales" and "museos escolares" in Mexico, "Ecomusée de la Haute Beauce» et "Ecomusée du Fier Monde» (Montreal) in Québec, "Ecomuseu do Seixal» in Portugal, "Toten økomuseum» in Norway, "Ekomuseum Bergslagen» in Sweden, "Ecomusée de Fourmies" in France, etc. An international group, affiliated to ICOM, was created by Canadians and Europeans under the name of MINOM (Mouvement International pour la Nouvelle Muséologie), under the chairmanship of Pierre Mayrand.

There were numerous international workshops held in Québec, Portugal, Spain, Norway, etc. The notion of the social role of museums was developed, discussed and studied, particularly in Portugal and Spain. In Northern Europe, it was more the question of mobilizing and strengthening the community that was debated. In France, the new museology was applied to problems like the conversion of industrial sites in crisis, the salvage of rural areas in the process of desertification, cultural tourism, etc. In 1986, at Jokkmokk in northern Sweden, a forum of oppressed minorities from all over the world discussed the question of the possible role of museums in helping these populations to liberate themselves by reinforcing their identities and defending their values.

At the same time, museology courses and publications began to include the new museology in their programmes. Some ICOM International Committees chose it as a topic for international seminars. The new type of museum could be described as essentially a cultural process, identified with a local community (population), on 
a specific territory, using the common heritage as a resource for development, as opposed to the more classical museum, an institution characterized by a collection, in a building, for a public of visitors.

But other divergent developments appeared in several countries. In France: the word «ecomuseum» became fashionable and was used for all kinds of technical, ethnographical, touristic so-called museums, as being more "modern», and potentially more attractive to visitors. This is why I, personally, refuse to talk anymore of ecomuseums as representing the new museums. I prefer to speak of «community museums».

However, in Spain (Parque Cultural de Molinos), the words "museum" or "ecomuseum» have been avoided altogether to create a similar kind of process, based more on the variety of resources existing on a given territory, not only to present them, but also to exploit them and draw from them social, cultural and economic benefits for the community.

\section{COMMUNITY MUSEUMS, THE BRAZILIAN EXPERIENCE OF THE 90s}

There are nowadays several countries where the new museology has recently taken a fresh turn, on a more permanent, if not to say institutional, basis. Mexico is one of them, Québec is another. I have been fortunate to witness, in the past four years, such a process in various parts of Brazil.

There, in local communities, in rural (Silveira Martins in Rio Grande do Sul), in urban (Novo Hamburgo, also in Rio Grande do Sul), as well as in underprivileged areas (Santa Cruz, a neighborhood of Rio de Janeiro), on the sites of major public works like hydro-electric power plants (Itaipu, Ita), the inhabitants themselves have discovered a sort of popular museology (but not always using the word museum), which is based on the total use of the cultural and natural heritage as development assets.

They are poor, sometimes to the point of survival, but they do not wait for public subsidies to be given to them. They invent their own solutions and they are slowly establishing a solidarity network amongst themselves. I counted more than twelve such experiments, at various stages of development. Even classical museums are transforming themselves to cater more for their local communities, whose members are no longer considered as visitors, or museum public, but as actors and subjects of the museum.

The museology courses, the professional seminars and journals are officially open to these ideas, which will help to define a specific museology for the future. I hope to be able to follow this evolution closely, as I am preparing with my Brazilian friends a book to be published simultaneously in Brazil and in Europe, on Heritage, Museums and Development.

\section{LIBERATION, DEVELOPMENT, NEW MISSIONS FOR THE MUSEUMS OF TOMORROW}

Last month, Professor Bedekar at the University of Baroda in India published a comprehensive book on "New Museology for India», and a seminar was held in New Delhi on this occasion at the end of March this year.

To me this is a clear demonstration that museums, at least in some crisis situations, 
HUGUES DE VARINE

26 are able to adapt to the new parameters of a changing society and to accept being used as development tools. A Museology of Liberation is emerging in places which were not, until now, on the museological maps, places where museums in the ordinary sense would not have been considered possible or acceptable, only a few years ago.

Such museums are different, because they concentrate, not on institutionalization, but on processes.

NOTE

The paper was presented in the seminar From Burgundy to Bergslagen, May 301996 at

Riksutställningar, Stockholm, in honour of Ulla Keding Olofsson.

Hugues de Varine discusses a similar topic, The local museum as a process in Nordisk Museologi $1996 / 1$. Professor Bedekar's work is referred to in this article.

Hugues de Varine var 1964-74 direktör för den internationella museiorganisationen ICOM. Han forestod under några år på 1980-talet Institut Français $i$ Lissabon. Sedermera han han arbetat med lokala sambällsutvecklingsuppdrag $i$ många länder. I bokform har han senast publicerat 'L'initiative communautaire' 1991.

Adr: F-21360 Lusigny-sur-Ouche e-mail:100342.615@compuserve.com 